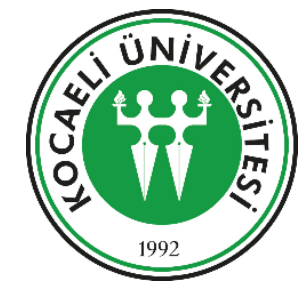

Kocaeli Üniversitesi Sağlık Bilimleri Dergisi

Özgün Araştırma / Original Article

http://dergipark.gov.tr/kusbed

\title{
OXIDANT-ANTIOXIDANT BALANCE CHANGES IN ADIPOSE TISSUES OF HIGH FAT DIET- INDUCED OBESE RATS: DEPOT-SPECIFIC MANNER AND INEFFECTIVENESS OF N- ACETYLCYSTEINE
}

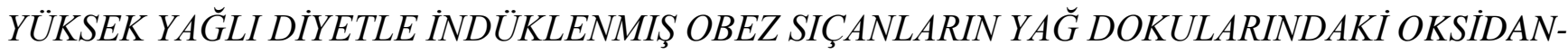 \\ ANTIOKSIDAN DENGE DEĞISŞIKLIKKLERI: DEPOYA ÖZGÜ TUTUM VE N-ASETILSISTEİNIN \\ ETKISIZZLI $\breve{G} \dot{I}$
}

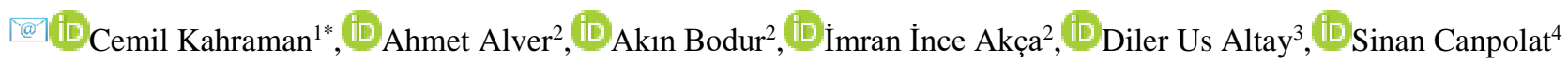

${ }^{1}$ Department of Nutrition and Dietetics, Faculty of Healt Sciences, Duzce University, Duzce, Turkey

${ }^{2}$ Department of Medical Biochemistry, Faculty of Medicine, Karadeniz Technical University, Trabzon, Turkey

${ }^{3}$ Ulubey Vocational School, Chemistry and Chemical Processing Technology Department, Laboratory Technology Program, Ordu, Turkey

${ }^{4}$ Department of Physiology, Faculty of Medicine, Firat University, Elazığ, Turkey

ORCID iD: Cemil Kahraman: 0000-0002-4494-6063; Ahmet Alver: 0000-0002-9617-6689; Akın Bodur: 0000-0001-7413-2717; İmran İnce Akça: 0000-0003-22323444; Diler Us Altay: 0000-0002-0465-8403; Sinan Canpolat: 0000-0002-1951-3987

*Sorumlu Yazar / Corresponding Author: Cemil Kahraman, e-posta / e-mail: cemilkahraman@duzce.edu.tr

Geliş Tarihi / Received: 17.12.2018

Kabul Tarihi / Accepted: 15.02.2019

Yayım Tarihi / Published: 20.05.2019

\begin{abstract}
Objective: The aims of study were to investigate effects of both N-acetylcysteine (NAC, an antioxidant) and high fat diet (HFD) to oxidative stress in differently located adipose tissues and the liver.

Methods: Our study is created from control, HFD and NAC groups $(n=6)$. Control group was fed with only standard diet. HFD group was fed with only HFD. NAC group was fed with HFD, and additionally that group received NAC (2 g/L). All groups were fed with designated diets for 85 days. Antioxidant enzyme activities, glutathione, and malondialdehyde were measured in epididymal, perirenal, subcutaneous adipose tissues, and liver. Results: In the HFD group, malondialdehyde (MDA) levels increased in perirenal adipose tissue and liver. In addition, superoxide dismutase (SOD) and catalase activities in the HFD group were lower both epididymal and perirenal adipose tissue, whereas glutathione peroxidase activities were lower in subcutaneous and epididymal adipose tissue. Glutathione was lower in liver tissue alone. In subcutan adipose tissue, the glutathione and SOD activities increased due to NAC administration.

Conclusion: The present findings showed that oxidative stress and antioxidant enzyme profiles were variable in localized adipose tissue in different regions. Thought antioxidant enzyme activities in some tissues increased due to NAC application, these increases were insignificant in terms of oxidant-antioxidant balance.
\end{abstract}

Keywords: Adipose tissue, glutathione peroxidase, high fat diet, malondialdehyde, $N$-acetylcysteine, oxidative stress

\section{$\ddot{O} z$}

Amaç: Çalışmanın amacı karaciğer ve farklı yerleşimli yağ dokularındaki oksidatif strese N-asetilsisteinin (NAC, antioksidan) ve yüksek yağlı diyetin (HFD) etkilerini araştırmaktır.

Yöntem: Çalışmamız kontrol, HFD ve NAC gruplarından oluşmaktadır ( $\mathrm{n}=6)$. Kontrol grubu standart diyetle, HFD grubu yüksek yă̆ içeren diyetle, NAC grubu ise yüksek yağlı yem ve içme suyuna katılan antioksidan molekül olan NAC ile beslendi ( $2 \mathrm{~g} / \mathrm{L})$. Tüm gruplar 85 gün boyunca ad libitum olarak beslendi. Beslenme periodunun sonunda karaciğer, subkutan, epididimal ve perirenal yağ dokularında antioksidan enzimler (süperoksit dismutaz, katalaz, glutatyon peroksidaz), glutatyon ve malondialdehit seviyeleri ölçüldü.

Bulgular: HFD grubunda malondialdehit (MDA) seviyesi karaciğer ve perirenal yağ dokusunda yüksekti. Ayrıca HFD grubunda süperoksit dismutaz (SOD) ve katalaz aktivitesi hem epididimal hemde perirenal yağ dokusunda, glutatyon peroksidaz aktivitesi epididimal ve subkutan yağ dokusunda düşüktü. Glutatyon ise sadece karaciğer dokusunda düşük tesbit edildi. NAC uygulaması subkutan yağ dokusunda SOD ve glutatyonu yükseltti.

Sonuç: Mevcut bulgular oksidatif stres ve antioksidan enzim profillerinin farklı bölgelerde yerleşmiş adipoz dokusunda değişken olduğunu, NAC uygulamasının bazı dokularda antioksidan enzim aktivitelerini artırmasına rağmen oksidan-antioksidan denge açısından önemli bir etkisinin olmadığını göstermektedir.

Anahtar Kelimeler: Adipoz doku, glutatyon peroksidaz, yüksek yağll diyet, malondialdehit, $N$-asetilsistein, oksidatif stres

Atıf Gösterimi/How to Cite: Kahraman C, Alver A, Bodur A, Akça AI, Altay DU, Canpolat S. Oxidant-antioxidant balance changes in adipose tissues of high fat diet-induced obese rats: Depot-specific manner and ineffectiveness of N-acetylcysteine. Kocaeli Üniversitesi Sağllk Bilimleri Dergisi. 2019;5(2):66-71. doi:10.30934/kusbed.498189 


\section{Introduction}

Obesity can be defined as a condition in which excessive energy is stored in white adipose tissue (WAT) as triacylglycerol. WAT is widely distribution across the body and is recognized as an important endocrine organ. Thus, WAT may have impact on the function of many systems. In obesity low-grade chronic systemic inflammation is often present. This situation is a result of the activation of the immune system by WAT which promotes pro-inflammatory status and oxidative stress, triggering a systemic acute-phase response. Obesity is risk factor of various chronic illnesses associated with oxidative stress, such as metabolic syndrome, diabetes mellitus, cardiovascular diseases and cancer. ${ }^{1-3}$

There are differences between adipose tissue located in subcutaneous areas and visceral adipose tissue (VAT) present in the abdomen. These differences include anatomical, cellular, hormonal, molecular, insulin sensitivity, physiological, metabolic and vascularization characteristics of the two types of adipose tissues. ${ }^{4}$ Anatomically, VAT is primarily found around the abdominal organs and secretes metabolites to the liver by portal circulation. Compared with subcutaneous adipose tissue (SCAT), VAT contains a rich neural network and is more vascularized. In addition, it is richer in terms of inflammatory and immune cells. Also, VAT has less preadipocyte differentiation capacity and larger adipocytes. ${ }^{5}$ In addition, there are site specific changes of redox metabolism and mitochondrial density between the types of adipose tissues. ${ }^{6-8}$

The predisposition to oxidative damage is even greater in obese subjects because of decreased antioxidant sources, including antioxidant enzymes such as superoxide dismutase (SOD), glutathione peroxidase (GPx), and catalase (CAT), as well as vitamin $A$, vitamin $E$, vitamin $C$, and $\beta$-carotene. ${ }^{9-11}$ SOD activity is considerably lower in obese human subjects compared with normal weight human subjects. ${ }^{12}$ In addition, anti-oxidant supplementation could reduce oxidative stress and other reactive oxygen species, thus decreasing the prevalence of complications which occur in obesity. ${ }^{3,6,13}$ However, contrary to classical inflammatory processes, reduced oxidative stress has been reported in differently located adipose tissues in recent studies. ${ }^{8,14}$

$\mathrm{N}$-acetylcysteine (NAC) is a compound that contains a thiol group with antioxidant and anti-inflammatory properties. NAC is the precursory compound of glutathione (GSH) which is a powerful antioxidant. Many studies have shown that NAC has beneficial effects against metabolic disorders. ${ }^{15-}$ 18

The aim of the present study was to investigate the oxidantantioxidant balance in differently located adipose tissues in an animal model of high-fat diet (HFD) induced obesity, and the efficacy of NAC as an antioxidant molecule in this model.

\section{Methods}

\section{Animals and experimental protocols}

The study protocol was reviewed and approved by Karadeniz Technical University Local Animal Care and Ethics Committee (Protocol No. 2010/39). All experimental procedures on animals were carried out in the KTU Surgical Application and Research Center.

Eighteen male Sprague-Dawley rats, aged about two months and weighing 200-250 g, were housed in polypropylene cages. The animals were divided into three experimental groups (see below). All groups were fed with one of two types of commercial standardized solid diets (both with equal calorie values) purchased from (Research Diets, New Brunswick, USA) standard diet (Product \#D12450B, composed of $65 \%$ carbohydrate, $30 \%$ protein, and $5 \%$ fat, by total energy), and HFD (Product \#12451, 45\% fat, 35\% carbohydrate and $20 \%$ protein, by total energy). All rats were housed under optimal laboratory conditions during the experiment (temperature of $21-23^{\circ} \mathrm{C}$, humidity of $50-60 \%$, 12:12 hour light: dark cycle) and received water and designated diets ad libitum.

During an adaptation period, all rats were fed with standard diet for 15 days. After the adaptation period, three experimental groups were formed, and fed with designated diets for 85 days. Control group $(n=6)$ : Fed with standard diet (Product \#D12450B). HFD group $(n=6)$ : Fed with HFD (Product \#D12451). NAC group $(n=6)$ : Fed with HFD (Product \#D12451) and received $2 \mathrm{~g} / \mathrm{L} \mathrm{N}$-acetylcysteine (Amresco, Solon, Ohio, USA) in the drinking water. Body weights were measured bi-weekly. After the feeding period, the rats were sacrified and blood was collected from the aorta. Epididymal adipose tissue (EAT), perirenal adipose tissue (PRAT), SCAT, and liver samples were removed, and collected under frozen carbon dioxide, then frozen at $-80^{\circ} \mathrm{C}$ until experimental analysis.

\section{Determination of metabolic parameters}

Serum insulin (DRG International Inc. Springfield, USA), serum leptin (BioVendor, Brno, Czech Republic), and serum adiponectin (Millipore, Burlington, USA) levels were measured using commercial ELISA kits according to the manufacturers' instructions. Serum glucose and triglyceride levels were measured by Roche Cobas 8000 Modular Autoanalyzer (Roche, Indianapolis, USA). Liver triglyceride content was determined using a total glycerol test kit (Roche) according to the manufacturer's instructions.

\section{Determination of malondialdehyde (MDA) levels}

Tissue samples (adipose tissue of $150 \mathrm{mg}$ and liver tissue of 50 to $60 \mathrm{mg}$ ) were minced and homogenized in $2 \mathrm{~mL}$ of an ice-cold $1.15 \% \mathrm{KCl}$ solution containing $0.5 \mathrm{~mL} / \mathrm{L}$ Triton $\mathrm{X}$ 100 using an Ultra-Turrax T25 homogenizer (IKA Labortechnik, Staufen, Germany). Liver tissue homogenates were used directly. However, adipose tissue homogenates were centrifuged at $1500 \mathrm{xg}$ for $10 \mathrm{~min}$. After centrifugation, upper lipid layers were discarded. $400 \mu \mathrm{L}$ ethanol/chloroform (2:3) mixture was added into $800 \mu \mathrm{L}$ supernatant and then centrifuged at $15000 \mathrm{xg}$ for $10 \mathrm{~min}$ at $+4^{\circ} \mathrm{C}$. The ethanol and chloroform phases were used in the MDA assay. MDA measurements were performed according to the metod of Mihara and Uchiyama. ${ }^{19}$ Tetramethoxypropane was used as a standard and MDA levels were calculated as nmol/g of wet tissue.

\section{Determination of SOD activity}

$150 \mathrm{mg}$ adipose tissue was homogenized in $2 \mathrm{~mL}$ of ice-cold $0.05 \mathrm{M}$ Tris-HCl buffer containing $0.5 \mathrm{~mL} / \mathrm{L}$ Triton $\mathrm{X}-100$ $(\mathrm{pH}=7.4)$. Adipose tissue homogenates were centrifuged at $1500 \mathrm{xg}$ for $10 \mathrm{~min}$. Upper lipid layers were discarded. Then, $0.4 \mathrm{~mL}$ ethanol/chloroform (2:3) mixture was added into 0.8 $\mathrm{mL}$ supernatant and then centrifuged at $10000 \mathrm{xg}$ for $30 \mathrm{~min}$ at $+4^{\circ} \mathrm{C}$. The ethanol phase was used for measuring SOD activity of adipose tissue. $50 \mathrm{mg}$ liver tissues were homogenized in $1 \mathrm{~mL}$ of ice-cold $0.05 \mathrm{M}$ Tris-HCl buffer $(\mathrm{pH}=7.4)$ and then centrifuged at $10000 \mathrm{xg}$ for $10 \mathrm{~min}$ at $+4^{\circ} \mathrm{C}$. Obtained supernatant was used for liver SOD activity 
measurement. The method of Sun and Oberley was used to measure SOD activities. ${ }^{20}$ The assessment was based on the reduction of nitroblue tetrazolium by a xanthine-xanthine oxidase system. Results were expressed as U/mg protein. Total protein concentrations of adipose and liver tissues were performed by the Bradford method. ${ }^{21}$

\section{Determination of CAT activity}

Supernatants were obtained, as described above. For adipose tissues, $1 \mathrm{~mL}$ supernatant was mixed with $300 \mathrm{~mL}$ chloroform and then centrifuged at $10000 \mathrm{xg}$ for $30 \mathrm{~min}$ at $+4^{\circ} \mathrm{C}$. CAT activity was measured in the upper phase. The method of Aebi was used to measure CAT activity. ${ }^{22}$ This method is based on dismutation rate of $\mathrm{H}_{2} \mathrm{O}_{2}$ at $240 \mathrm{~nm}$. CAT activities were expressed as $\mathrm{k} / \mathrm{g}$ protein ( $\mathrm{k}$, rate constant).

\section{Determination of GPx Activity}

GPx activity measurements were performed with a commercial assay kit (Cayman Chemical Company, Ann Arbor, USA). In this kit, GPx activity is coupled with the oxidation of NADPH by glutathione reductase. Oxidation of NADPH was followed spectrophotometrically at $340 \mathrm{~nm}$ at $25^{\circ} \mathrm{C}$. Supernatants of adipose tissue samples were obtained, as described previously. For liver tissue samples, homogenization steps were performed as per the assay kit protocol. Results were expressed as $\mathrm{nmol} / \mathrm{min} / \mathrm{mg}$ protein.

\section{Determination of GSH Levels}

$250 \mathrm{mg}$ adipose tissues were homogenized in $1.5 \mathrm{~mL}$ buffer (4 g NaCl, 0.1 g KCl, 0.9 g $\mathrm{Na}_{2} \mathrm{HPO}_{4} \cdot 2 \mathrm{H}_{2} \mathrm{O}, 0.14$ g $\mathrm{KH}_{2} \mathrm{PO}_{4}$, and $350 \mu \mathrm{L}$ Triton $\mathrm{X}-100$ in $0.5 \mathrm{~L}$ distilled water, $\mathrm{pH}$ 7.4). The samples were centrifuged at $1500 \mathrm{xg}$ for $5 \mathrm{~min} .1$ $\mathrm{mL}$ supernatant and $300 \mu \mathrm{L}$ chloroform were mixed, vortexed and centrifuged at $10000 \mathrm{xg}$ for $15 \mathrm{~min}$ at $+4^{\circ} \mathrm{C}$. Obtained supernatant was used for GSH measurement. $50 \mathrm{mg}$ liver tissues were homogenized in $1 \mathrm{~mL}$ ice-cold $0.05 \mathrm{M}$ Tris- $\mathrm{HCl}$ buffer ( $\mathrm{pH}=7.4)$.

GSH levels were measured by the method of Garcia and colleagues $^{23}$ by high-performance liquid chromatography (Agilent 1100, Agilent Technologies, Waldbronn, Germany). $0.1 \mathrm{~mL}$ homogenate was added to $40 \mu \mathrm{L} 0.3 \mathrm{mM}$ EDTA solution and then mixed with $0.1 \mathrm{~mL} 20 \%$ Triton X-100 by vortex-mixing for $1 \mathrm{~min}$. Deproteinization was achieved by adding $0.1 \mathrm{~mL}$ of $15 \%$ trichloroacetic acid and centrifuging at $18000 \mathrm{xg}$ for $10 \mathrm{~min}$. The derivatization reaction was performed utilizing $0.13 \mathrm{~mL}$ supernatant, $0.5 \mathrm{~mL} 0.5 \mathrm{M}$ Tris$\mathrm{HCl}$ buffer ( $\mathrm{pH}=8.9$ ), and $0.35 \mathrm{~mL} 5 \mathrm{mM}$ DTNB (in $0.5 \mathrm{M}$ $\mathrm{K}_{2} \mathrm{HPO}_{4}, \mathrm{pH}=8.0$ ). This mixture was incubated in an ice bath for $5 \mathrm{~min}$, and then it was acidified by addition of $0.1 \mathrm{~mL} 7 \mathrm{M}$ $\mathrm{H}_{3} \mathrm{PO}_{4}$ and then centrifuged at $3000 \mathrm{xg}$ for $10 \mathrm{~min}$ at $+4^{\circ} \mathrm{C}$. Then, derivatized samples were filtered through a $0.22 \mu \mathrm{m}$ membrane. $20 \mu \mathrm{L}$ of each filtrate were injected into the column (ZORBAX Eclipse XDB-C18; 4.6x150mm; $5 \mu \mathrm{m}$, Agilent Technologies, Santa Clara, USA). The mobile phase consisted of a mixture of $0.025 \mathrm{M} \mathrm{KH}_{2} \mathrm{PO}_{4}(\mathrm{pH}=3.8)$ and methanol. GSH levels were expressed as $\mathrm{mM} / \mathrm{g}$ protein.

\section{Statistical analysis}

Descriptive statistical analysis was performed for all studied variables. Kolmogorov-Smirnov test was performed to determine the normal distributions. The differences between groups were investigated by Kruskal Wallis test. MannWhitney U test was chosen for post-hoc. Statistical analyses were performed using SPSS 16.0 computer software. Statistically significance was set at $p<0.05$.

\section{Results}

The levels of blood glucose, triglyceride, insulin, leptin and adiponectin following the diet period are summarized in Table 1. Compared with the standard diet group, HFD resulted in a significant body weight increase $(450.3 \pm 31.3 \mathrm{~g}$ versus $517.8 \pm 19.9 \mathrm{~g}$, respectively; $p=0.018$ ). At the end of diet program serum glucose levels were found to be higher in the HFD group compared to control $(150.0 \pm 12.5 \mathrm{mg} / \mathrm{dL}$ versus $130.3 \pm 7.6 \mathrm{mg} / \mathrm{dL}$, respectively; $p=0.004)$. Serum leptin levels were significantly higher in the HFD group than control group $(13.8 \pm 4.1 \mathrm{ng} / \mathrm{mL}$ versus $6.1 \pm 1.4 \mathrm{ng} / \mathrm{mL}$, respectively; $p=0.003)$. There were no differences between the experimental groups for triglyceride, insulin or adiponectin concentrations. In liver tissue, triglyceride levels were higher in the HFD and NAC groups than in the control group ( $p=0.002$ and $p=0.009$, respectively). In addition, NAC administration did not change any of the mentioned parameters in HFD fed rats ( $p>0.05$, compared to HFD group).

Table 1. Initial body weight and alterations of metabolic parameters were given as $\mathrm{X} \pm \mathrm{SD}$

\begin{tabular}{l|ccc}
\hline & $\begin{array}{c}\text { Control } \\
\text { group }\end{array}$ & HFD group & NAC group \\
\hline Initial body weight $(\mathrm{g})^{\mathrm{I}}$ & $285 \pm 21.3$ & $283.5 \pm 25.2$ & $284.5 \pm 21.47$ \\
Final body weight $(\mathrm{g})$ & $450.3 \pm 31.3$ & $\mathbf{5 1 7 . 8} \pm \mathbf{1 9 . 9}^{*}$ & $\mathbf{5 1 4 . 0} \pm \mathbf{6 5 . 2}^{*}$ \\
Glucose $(\mathrm{mg} / \mathrm{dL})$ & $130.3 \pm 7.6$ & $\mathbf{1 5 0 . 0} \pm \mathbf{1 2 . 5}^{*}$ & $\mathbf{1 6 0 . 1}^{*} \mathbf{1 6 . 8}^{*}$ \\
TG $(\mathrm{mg} / \mathrm{dL})$ & $177.8 \pm 47.9$ & $188.6 \pm 53.9$ & $153.1 \pm 44.7$ \\
Insulin $(\mathrm{pmol} / \mathrm{L})$ & $264 \pm 59.1$ & $293.2 \pm 59.9$ & $313.1 \pm 80.1$ \\
Leptin $(\mathrm{ng} / \mathrm{mL})$ & $6.1 \pm 1.4$ & $\mathbf{1 3 . 8}^{*} \pm \mathbf{4 . 1}^{*}$ & $\mathbf{1 4 . 4}^{*}$ \\
Adiponectin $(\mu \mathrm{g} / \mathrm{mL})$ & $25.4 \pm 7.9$ & $24.1 \pm 4.1$ & $23.6 \pm 4.9$ \\
Liver TG content & $3.3 \pm 0.2$ & $\mathbf{4 . 7}^{*} \pm \mathbf{0 . 6}^{*}$ & $\mathbf{4 . 0}^{*} \mathbf{0 . 4}^{*}$ \\
(mg/g wet tissue) & & &
\end{tabular}

I: Body weight after fifteen days pre-feeding; $X=$ Arithmetic Mean, $S D=$ Standard Deviation. ${ }^{*} p<0.05$, compare to control group.

MDA measurements in PRAT revealed that MDA levels were significantly higher in the HFD group compared to controls $(p=0.002)$. In SCAT, MDA levels were significantly lower in the HFD group than in the control group $(p=0.041)$. While NAC administration increased MDA level in SCAT ( $p=0.015$ ), that did not change in other tissues. In EAT, MDA levels showed no difference between groups. In liver, MDA levels were higher in the HFD group than in the control group $(p=0.009)$. NAC administration did not change MDA levels in this tissue (Fig. 1).

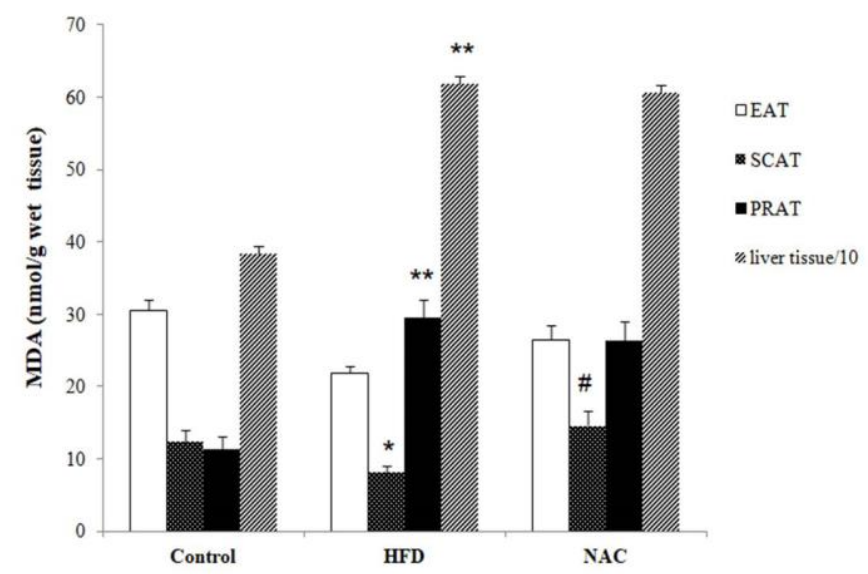

Figure 1. MDA levels in different located adipose tissues and liver. ${ }^{*} p<0.05$, compare to control group, ${ }^{* *} p<0.01$, compare to control group, ${ }^{*} p<0.05$, compare to HFD group). EAT, epididymal adipose tissue; MDA, malondialdehyde; SCAT, subcutaneous adipose tissue; HFD, high-fat diet; NAC, N-acetylcysteine; PRAT, perirenal adipose tissue

HFD resulted in reduced SOD activity compared to the control group in PRAT and EAT $(p=0.03$ and $p=0.04$, respectively). In SCAT, NAC administration significantly 
increased SOD activity ( $p=0.02)$. In liver, SOD activities showed no difference between the groups (Fig. 2).

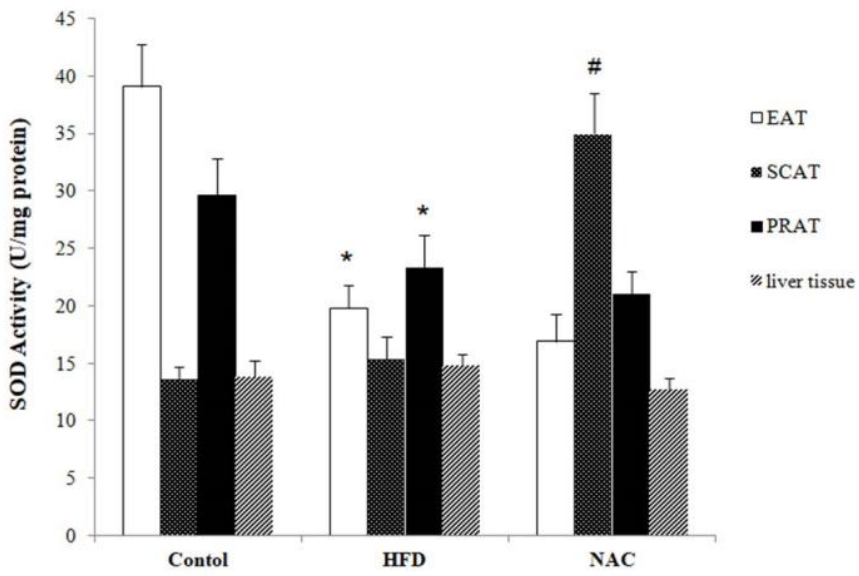

Figure 2. SOD activities in different located adipose tissues and liver. ${ }^{*} p<0.05$, compare to control group, ${ }^{\#} p<0.05$, compare to HFD group). EAT, epididymal adipose tissue; SOD, superoxide dismutase; SCAT, subcutaneous adipose tissue; HFD, high-fat diet; NAC, N-acetylcysteine; PRAT, perirenal adipose tissue

In EAT and PRAT, CAT activities were found to be decreased in the HFD group compared with the control group ( $p=0.04$ and $p=0.02$, respectively). Although CAT activity was higher in the NAC administered group, only in the EAT did the difference reach a significant level $(p=0.002)$. In SCAT, CAT activities showed no differences between groups. While CAT activity was significantly reduced in HFD ( $p=0.002)$, NAC administration reversed that effect to control levels in liver (Fig. 3).

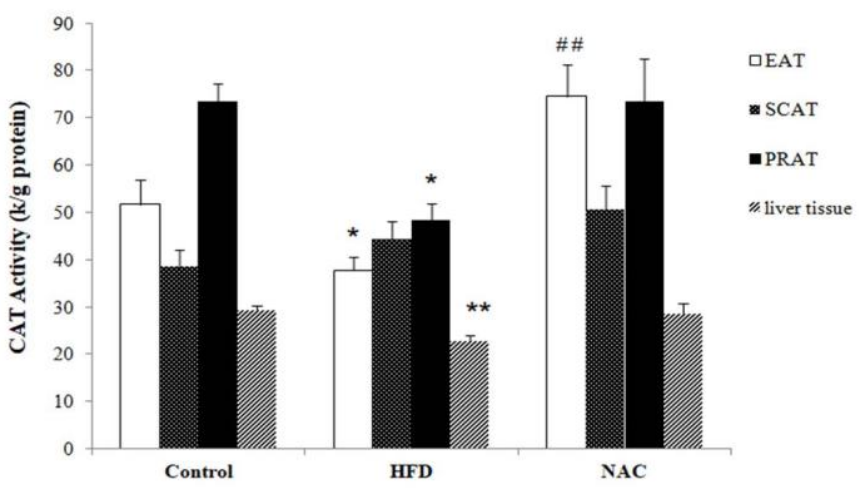

Figure 3. CAT activities in different located adipose tissues and liver. $\left({ }^{*} p<0.05\right.$, compare to control group, ${ }^{* *} p<0.01$, compare to control group, ${ }^{\# \#} p<0.01$, compare to HFD group). EAT, epididymal adipose tissue; CAT, catalase; SCAT, subcutaneous adipose tissue; HFD, high-fat diet; NAC, N-acetylcysteine; PRAT, perirenal adipose tissue

GPx activities were shown considerably decreased in SCAT and EAT of HFD-fed rats $(p=0.009$ and $p=0.002$, respectively). NAC administration considerably increased GPx activity only in SCAT ( $p=0.015$ ). In liver, GPx activity was considerably higher in the HFD group than in the control group $(p=0.02)$. In the HFD group, NAC administration increased GPx activity towards normal control values, but the difference did not reach significance ( $p=0.065$ ) (Fig. 4).

We observed that GSH levels were increased due to HFD, yet these increases were statistically not significant. Similarly, NAC administration increased GSH levels in all tissues, but the increase only reached a statistically significant level in SCAT $(p=0.004)$. Liver GSH levels were significantly lower in the HFD group than in control group $(p=0.002)$. In liver, NAC administration significantly increased the GSH levels compared to the HFD group ( $p=0.041$ ) (Fig. 5).

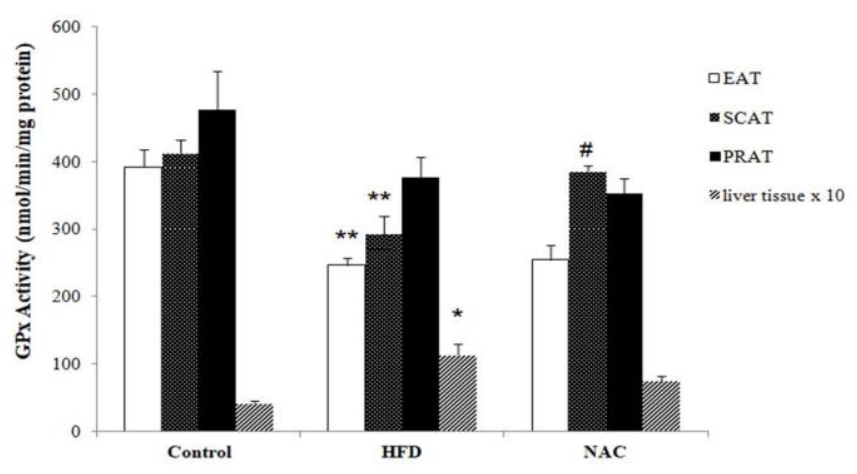

Figure 4. GPx activities in different located adipose tissues and liver. $\left({ }^{*} p<0.05\right.$, compare to control group ${ }^{* *} p<0.01$, compare to control group, ${ }^{\#} p<0.05$, compare to HFD group). EAT, epididymal adipose tissue; GPx, glutathione peroxidase; SCAT, subcutaneous adipose tissue; HFD, high-fat diet; NAC, N-acetylcysteine; PRAT, perirenal adipose tissue

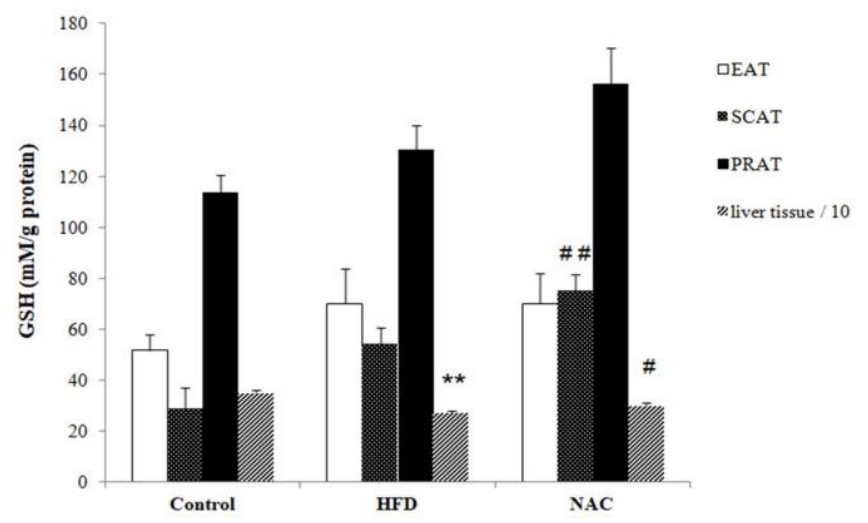

Figure 5. GSH levels in different located adipose tissues and liver. $\left({ }^{\#} p<0.05\right.$, compare to HFD group, ${ }^{\#} p<0.01$, compare to HFD group, ${ }^{* *} p<0.01$, compare to control group). EAT, epididymal adipose tissue; GSH, glutathione; SCAT, subcutaneous adipose tissue; HFD, high-fat diet; NAC, N-acetylcysteine; PRAT, perirenal adipose tissue

\section{Discussion}

Adipose tissue is localized in different areas of the body. Different localization is accompanied by different structural organization, cellular dimensions and biological functions. In general, SCAT stores triglyceride and VAT is involved in the regulation of metabolic functions. ${ }^{4}$ Different kinds of adipose tissues exhibit variations in the secreted adipokines. ${ }^{5,24}$ In obese humans and animal models, oxidative stress markers were reported to be elevated. In addition, oxidative stress markers caused insulin resistance in 3T3-L1 cells. These findings connected obesity, obesity-induced insulin resistance and propensity for developing Type-2 diabetes to oxidative stress. $^{12,25}$ In obesity, the potential mechanisms which contribute to oxidative stress are mitochondrial dysfunction, hyperglycemia, increased muscle activity, high tissue lipid levels, insufficient oxidative defense, endothelial reactive oxygen species (ROS) production and hyperleptinemia. ${ }^{12,24}$ In addition, obesity is characterized by a low grade chronic inflammatory process which involves the infiltration of macrophages into adipose tissue. ${ }^{2,8}$

In our study, MDA levels were higher in PRAT of rats fed with HFD. However, such increases were not observed in SCAT and EAT (Fig 1). Similar results were reported in different animal models and diet protocols. ${ }^{7,14,26}$ The distinct responses of adipose tissues are likely to be a result of tissue specific metabolic properties. Recent studies have connected mitochondrial content and function in adipose tissue to metabolic diseases. ${ }^{24,27}$ In obesity, mitochondrial ROS production is increased in adipose tissue and mitochondrial density varies depending on the anatomical location of adipose tissue. ${ }^{16}$ For example, epididymal adipocytes contain higher number of mitochondria than inguinal adipocytes in 
rats. ${ }^{6}$ Alternatively, different MDA levels of adipose tissues might be due to the differences of stromal vascular fractions. Macrophage infiltration rate is slower in SCAT. Thus, reactive aldehyde species are less concentrated in this tissue. In SCAT, several antioxidant genes such as peroxiredoxin 3 and aldehyde dehydrogenase 2 are not down-regulated by HFD which leads to a stronger antioxidant defense and lower levels of aldehyde species. ${ }^{8}$ Besides, potential variations in NADPH oxidase, which is an important source of oxidative stress in adipose tissue, might have an impact on different MDA levels. MDA levels were higher in the HFD group in liver ( $p=0.009$ ) (Fig 1). In liver, upon HFD consumption, to compensate for the high amounts of ingested fatty acids the genes involved in fatty acid oxidation are up-regulated. However, mitochondrial respiratory chain components are down-regulated. As a result, high amounts of electrons enter into the respiratory chain and mitochondrial ROS are formed due to abnormal reduction of oxygen. In addition, in the liver, upon suppression of the components of the respiratory chain, some of these electrons are taken into the peroxisome and microsome, and more ROS may be produced by acylcoenzyme A oxidase and cytochrome P450 2E1. ${ }^{28}$

Enzymatic and non-enzymatic antioxidant defense has critical importance for maintenance of oxidant-antioxidant homeostasis. In obese individual vitamins $\mathrm{E}$ and $\mathrm{C}$, carotenes, phytochemicals, zinc, copper, selenium, SOD, CAT, and GPx were found to be at lower concentration than in non-obese individuals. $^{12}$ These results suggest that insufficient antioxidant defense occurs in obesity. In this dietary model, measured antioxidant enzyme activities display different profiles in different adipose tissues (Fig 2-4). However, in general enzyme activities were lower in the HFD group. In obese animal models, studies based on biochemical measurements demonstrated similar tissue specific differences. ${ }^{3,26}$ NAC administration increased SOD and GPX activities in SCAT. This elevated antioxidant activity may have led to decreased MDA levels. Similarly, EAT showed increased CAT activity and decreased MDA levels following NAC administration (Fig 3). In liver, upon HFD consumption GPx activity was observed to increase which we suggest is to compensate for increased intracellular oxidative stress. NAC administration did not further affect the antioxidant enzyme activity in this tissue (Fig 4).

A positive link was reported between GSH and lipid storage in adipose cells. ${ }^{9}$ In rats, buthionine sulfoximine (glutathione synthase inhibitor) led to smaller adipose cells and reduced body weight. Besides, GSH depletion prevented HFD induced obesity and increases insulin sensitivity..$^{29,30}$ In our study, NAC, a GSH precursor, increased GSH levels in all tissues. GSH is an important component of antioxidant defense systems. In spite of decreased antioxidant enzyme activities in adipose tissues, MDA levels did not show a considerable change. Increased GSH might have played a role in this situation. However other antioxidant enzymes and sources that we did not measure in our study might have contributed to this effect. In liver, HFD decreased the GSH levels and NAC administration increased GSH levels (Fig 5). In many studies, oxidative stress results and antioxidant parameters are inconsistent. ${ }^{7,14,26}$ This inconsistency stems from a lack of standard procedures for obesity models other than diet induced models. Differences in experimental protocols such as species and strains of experimental animals, age at start of the diet and variable diet periods and fatty acid (especially polyunsaturated fatty acids) content of different HFD has led to different reported metabolic outcomes in HFD-induced obesity models. ${ }^{31}$ Different adipose tissues with different anatomical locations have different mitochondrial densities $^{6}$, NADPH oxidase activity, Vitamin E levels, fatty acid content of stored TAG droplets. ${ }^{2,31,32}$ In addition stromal vascular fraction differences might explain the inconsistency of the results. ${ }^{1}$ Besides, the methods used for oxidative stress evaluation in adipose tissue and lipid interference in these measurements could have led to different results.

In conclusion, in obesity models induced by HFD, oxidative stress and antioxidant enzyme profiles of adipose tissues located in different anatomical regions showed certain variations. NAC administration did not have an additional effect on oxidative stress and antioxidant enzyme activities in adipose tissues in our model.

\section{Acknowledgement}

The financial fund of this study was provided by TUBITAK (111S252).

\section{References}

1. Caruso C, Balistreri CR, Candore G. The role of adipose tissue and adipokines in obesity-related inflammatory diseases. Mediators Inflamm. 2010. doi:10.1155/2010/802078

2. Fernández-Sánchez A, Madrigal-Santillán E, Bautista $\mathrm{M}$, et al. Inflammation, oxidative stress, and obesity. Int J Mol Sci. 2011. doi:10.3390/ijms12053117

3. Furukawa S, Fujita T, Shimabukuro M, et al. Increased oxidative stress in obesity and its impact on metabolic syndrome. J Clin Invest. 2004. doi:10.1172/JCI21625

4. Kwok KHM, Lam KSL, Xu A. Heterogeneity of white adipose tissue: Molecular basis and clinical implications. Exp Mol Med. 2016. doi:10.1038/emm.2016.5

5. Ibrahim MM. Subcutaneous and visceral adipose tissue: Structural and functional differences. Obes Rev. 2010. doi:10.1111/j.1467-789X.2009.00623.x

6. Deveaud C, Beauvoit B, Salin B, Schaeffer J, Rigoulet M. Regional differences in oxidative capacity of rat white adipose tissue are linked to the mitochondrial content of mature adipocytes. Mol Cell Biochem. 2004.

7. Galinier A, Carriere A, Fernandez Y, et al. Site specific changes of redox metabolism in adipose tissue of obese Zucker rats. FEBS Lett. 2006. doi:10.1016/j.febslet.2006.10.052

8. Long EK, Olson DM, Bernlohr DA. High-fat diet induces changes in adipose tissue trans-4-oxo-2-nonenal and trans-4-hydroxy-2-nonenal levels in a depot-specific manner. Free Radic Biol Med. 2013. doi:10.1016/j.freeradbiomed.2013.05.030

9. Amirkhizi F, Siassi F, Minaie S, Djalali M, Rahimi A, Chamari M. Is obesity associated with increased plasma lipid peroxidation and oxidative stress in women? ARYA Atheroscler. 2007.

10. Ozata M, Mergen M, Oktenli C, et al. Increased oxidative stress and hypozincemia in male obesity. Clin Biochem. 2002. doi:10.1016/S0009-9120(02)00363-6

11. Vincent HK, Vincent KR, Bourguignon C, Braith RW. Obesity and postexercise oxidative stress in older women. Med Sci Sports Exerc. 2005 doi:10.1249/01.MSS.0000152705.77073.B3

12. Ma Y, Gao M, Liu D. N-acetylcysteine Protects Mice from High Fat Diet-induced Metabolic Disorders. Pharm Res. 2016. doi:10.1007/s11095-016-1941-1

13. Jones DA, Prior SL, Barry JD, Caplin S, Baxter JN, Stephens JW. Changes in markers of oxidative stress and DNA damage in human visceral adipose tissue from subjects with obesity and type 2 diabetes. Diabetes Res Clin Pract. 2014. doi:10.1016/j.diabres.2014.09.054

14. Song D, Hutchings S, Pang CCY. Chronic N-acetylcysteine prevents fructoseinduced insulin resistance and hypertension in rats. Eur J Pharmacol. 2005. doi:10.1016/j.ejphar.2004.12.018

15. Talior I, Yarkoni M, Bashan N, Eldar-Finkelman H. Increased glucose uptake promotes oxidative stress and PKC- $\delta$ activation in adipocytes of obese, insulinresistant mice. Am J Physiol Metab. 2015. doi:10.1152/ajpendo.00044.2003

16. Tanaka Y, Gleason CE, Tran POT, Harmon JS, Robertson RP. Prevention of glucose toxicity in HIT-T15 cells and Zucker diabetic fatty rats by antioxidants. Proc Natl Acad Sci. 1999. doi:10.1073/pnas.96.19.10857

17. Yang RL, Le G, Li A, Zheng J, Shi Y. Effect of antioxidant capacity on blood lipid metabolism and lipoprotein lipase activity of rats fed a high-fat diet. Nutrition. 2006. doi:10.1016/j.nut.2006.08.018

18. Mihara M, Uchiyama M. Determination of malonaldehyde precursor in tissues by thiobarbituric acid test. Anal Biochem. 1978. doi:10.1016/0003-2697(78)90342-1.

19. Sun Y, Oberley LW, Li Y. A simple method for clinical assay of superoxide dismutase. Clin Chem. 1988.

20. Bradford MM. A rapid and sensitive method for the quantitation of microgram quantities of protein utilizing the principle of protein-dye binding. Anal Biochem. 1976. doi:10.1016/0003-2697(76)90527-3

21. Aebi H. [13] Catalase in Vitro. Methods Enzymol. 1984. doi:10.1016/S00766879(84)05016-3

22. Garcia SC, Schott K, Charão M, et al. Quantification of reduced gluthatione by HPLC-UV in erythrocytes of hemodialysis patients. Biomed Chromatogr. 2008. doi:10.1002/bmc.954

23. Bjørndal B, Burri L, Staalesen V, Skorve J, Berge RK. Different Adipose Depots: Their Role in the Development of Metabolic Syndrome and Mitochondrial Response to Hypolipidemic Agents. J Obes. 2011. doi:10.1155/2011/490650

24. Lin Y, Berg AH, Iyengar P, et al. The hyperglycemia-induced inflammatory response in adipocytes: The role of reactive oxygen species. J Biol Chem. 2005. doi:10.1074/jbc.M411863200

25. Galinier A, Carrière A, Fernandez Y, et al. Adipose tissue proadipogenic redox changes in obesity. J Biol Chem. 2006. doi:10.1074/jbc.M506949200 
26. Parish R, Petersen KF. Mitochondrial dysfunction and type 2 diabetes. Curr Diab Rep. 2005. doi:10.1007/s11892-005-0006-3

27. Lowell BB, Shulman GI. Mitochondrial dysfunction and type 2 diabetes. Science 2005;307(5708):384-387. doi:10.1126/science.1104343.

28. Matsuzawa-Nagata $\mathrm{N}$, Takamura $\mathrm{T}$, Ando $\mathrm{H}$, et al. Increased oxidative stress precedes the onset of high-fat diet-induced insulin resistance and obesity. Metabolism. 2008. doi:10.1016/j.metabol.2008.03.010

29. Findeisen HM, Gizard F, Zhao Y, et al. Glutathione depletion prevents dietinduced obesity and enhances insulin sensitivity. Obesity. 2011. doi:10.1038/oby.2011.298

30. Ogihara $\mathrm{T}$, Asano $\mathrm{T}$, Katagiri $\mathrm{H}$, et al. Oxidative stress induces insulin resistance by activating the nuclear factor- $\kappa \mathrm{B}$ pathway and disrupting normal subcellular distribution of phosphatidylinositol 3-kinase. Diabetologia. 2004. doi:10.1007/s00125-004-1391-x

31. Malcolm GT, Bhattacharyya AK, Velez-Duran M, Guzman MA, Oalmann MC, Strong JP. Fatty acid composition of adipose tissue in humans: Differences between subcutaneous sites. Am J Clin Nutr. 1989. doi:10.1093/ajcn/50.2.288.

32. Garaulet M, Pérez-Llamas F, Pérez-Ayala M, et al. Site-specific differences in the fatty acid composition of abdominal adipose tissue in an obese population from a mediterranean area: Relation with dietary fatty acids, plasma lipid profile, serum insulin, and central obesity. Am J Clin Nutr. 2001.doi:10.1093/ajcn/74.5.585. 